\title{
Utilisation of Modern Processing Technologies among Shea Butter Processors in Niger State, Nigeria \\ https://dx.doi.org/10.4314/jae.v22i2.9
}

\section{Sanusi Mohammed Kabiru}

Nigerian Institute for Oil Palm Research (NIFOR)

Date palm Sub-station, Dutse, Jigawa State, Nigeria.

Email: sanusimk2004@gmail.com.

Phone: 08033638872.

\section{Tijani Sarafat Ayanfunke}

Department of Agricultural Extension and Rural Development, Faculty of Agriculture, University of Ibadan, Ibadan.

Email: tsarafat@yahoo.com.

Phone: 08051370802.

\section{Abstract}

The study assessed the level of utilization of modern processing technologies among processors in Niger State, Nigeria. Multi-stage sampling procedure was used to select 217 respondents for this study. Interview schedule was used to collect data which were analysed with descriptive and inferential statistics. Generally, the level of utilization of modern processing technology was low (57.6\%). However, milling to fine paste $(\mu=1.97)$, use of matured, fresh and un-cracked nuts $(\mu=1.91)$, Keep butter in cool and dry place $(\mu=1.90)$ and milling machine $(\mu=1.86)$ were the most utilized technologies. The respondents identified lack of credit facility $(\mu=1.72)$, lack of government assistance $(\mu=1.68)$ and high cost of processing equipment $(\mu=1.67)$ as constraints to use modern processing technologies. There was significant relationship between respondent's age $(r=0.245, p=0.00)$, years of experience $(r=0.198, p=-0.004)$, constraints $(r=0.152, p=-0.027)$ and awareness $(r=0.792, p=0.00)$ with their level of utilization of modern processing technologies. Niger State Commodity Export Promotion council should make effort to increase the number of Shea butter processing villages across the state and extension service in the state needs to be invigorated to adopt Shea programme seriously to be able to reach-out to more processors.

Keywords: Utilisation, modern processing technologies, Shea butter, awareness, Niger State,

\section{Introduction}

The importance of Shea tree to Nigeria economy is not in doubt, but the quality of the butter that is produced is poor owing to the method of production (Ademola, Oyesola and Osewa, 2012; Akinsokeji, Tijani, Sanusi, Igene and Orifah (2017). The level of utilization of modern processing techniques has direct effect on the capacities of the processors in term of the quality and quantity of Shea butter produced. As reported by 
Creative commons User License: CC BY-NC-ND

Abstracted by: EBSCOhost, Electronic Journals Service (EJS), Google Scholar, Journal Seek, Scientific Commons,

Food and Agricultural Organization (FAO), CABI and Scopus
Journal of Agricultural Extension

Vol. 22 (2) June, 2018

ISSN(e): 24086851; ISSN(Print); 1119944X

http://journal.aesonnigeria.org

Email: editorinchief@aesonnigeria.org

Addaquay (2004) and Akinsokeji, et. al. (2017), comparatively, the extraction rate of Shea butter from Vitellaria paradoxa using the traditional method is about $20 \%$, while using semi-mechanised method is $35 \%$ to $40 \%$ and the fully mechanised method is $42 \%$ to $50 \%$. The crushing process, traditionally done with mortar and pestle is replaced with a hammer mill while milling which is done using grinding stone is replaced with a modified (corn) mill that grind roasted Shea nuts into fine paste. Kneader has also been fabricated to replace the traditional manual hand and pedalling kneading process (Daniel et al, 2005; Sanusi, Tijani and Akinsokeji, 2016). Niger State being the largest producer of the Shea nuts is considering Shea as a potential cash crop in the State, hence her collaboration with an international partner, Deutshe Gesellschaft Für internationale Zusammenarrbeit (GIZ) GmbH, a German Cooperation mission in Nigeria.

Deutshe Gesellschaft Fūr internationale Zusammenarrbeit initiated a baseline surveyed in 2007 that revealed that the Shea sector performance in Niger State is below expectation, despite the huge potentials and that large quantities of the nuts are constantly being exported without value addition. They cited among others, absence of reliable data and sustainable policy for planning and promotion of the industry, poor quality nuts and butter, lack of commercial practice/ operation resulting in low production capacity, lack of organized groups or cooperatives along the value chain for better performance of the sector, use of traditional processing technology and equipment for processing, weak enforcement and legislation on indiscriminate cutting of Shea trees and poor access to quality water as well as very limited effective agricultural extension support (Ebayahaya, 2014).

Consequently, Niger State government and other development partners like GIZ set up interventions to address the problems. The interventions in the Shea sector includes hiring of consultants and collaborating with development partners in the industry to conduct Shea sensitization programme at community level with Shea groups across the state for them to understand that Shea is a business and to form a functional cooperatives Organized training of trainers (TOT) on best practices to handle and store Shea nuts as well as training on Shea butter quality improvement for Principal Women Development Officers (PWDOs), the Women In Agriculture programme (WIA), the Block Extension Supervisors (BES) and the National Shea Products Association of Nigeria (NASPAN) members for onward replication with Shea groups. They also introduce modern processing technology through development of package on Shea butter best practices that contain simple guide to following in order to produce quality butter with or without machine in the English language and translated to the Nupe and Hausa languages whom are identified to be major language in the State. (Ebayahaya, 2014).

Lastly, GIZ-SEDIN in conjunction with Niger State Commodity Export Promotion Council (NSCEPC) had facilitated the introduction of Shea butter villages (SBVs) in Kodo, Farin Shinge and Assanyi in the three Niger State Agricultural Mechanization Development Agency zones of the state where equipment such as power machine, crusher, miller, source of water, generator and roaster are provided in addition to training. (Ebayahaya, 2014). Similarly, there was another processing site at Babaji in Katcha Local Government Area of the State jointly established by Nigerian Export 
Promotion Council (NEPC) through World Trade organization (WTO) and Niger State government where equipment such as cracker, dryer, crusher, miller, water source, generator, kneader and roaster were provided. These interventions are aimed at improving the capacity of Shea butter processors through increase in production of butter in terms of quality and quantity in the State, thereby increasing their income and that of the other stakeholders along the value chain.

However, GIZ have discontinued their participation in Shea butter project. How this has fared in the state is yet to be determined. In addition many research works have been carried out on Shea butter such as the quantity of Shea nuts assessed, collected and process using improved Shea nut processing technologies in Niger State (Koloche, Hamza, Mohammed, Yahaya, Garbaand Oladipo 2016), Socioeconomic characteristics and constraints associated with adoption of improved Shea nut processing technologies in Niger State (Koloche, Olaleye, Adeniji, Yahaya, Umar and Tsado, 2016), processors' training needs on modern Shea butter processing technologies in North central Agro-ecological zone of Nigeria (Igene, Sedibe, Solomon, Van der Westhuizen and Fadeyi 2017) but none on the level of utilisation of modern processing technologies in Niger State. This necessitated the need to assess the level of utilization of modern processing technologies by the processors in Niger State in a view to ascertain the impact of the interventions that are aimed to improve the usage of modern processing technologies in enhancing the production capacities of the Shea butter processors in the state.

The general objective of this study was to examine the level of utilisation of modern processing technologies among Shea butter processors in Niger State, Nigeria. The specific objectives were to:

1. describe the personal characteristics of Shea butter processors;

2. identify the enterprise characteristics of the processors;

3. ascertain sources of information on modern Shea butter processing technologies;

4. ascertain level of awareness of modern Shea butter processing technologies;

5. identify the constraints facing the processors in the use of the modern processing technologies; and

6. Determine the level of utilisation of modern processing technologies.

\section{Hypotheses}

Ho1: There is no significant relationship between age/years of experience/awareness of the respondents and level of utilisation of modern processing technologies.

Ho2: There is no significant relationship between constraints to modern Shea butter processing technology and level of utilisation of modern processing technologies.

\section{Methodology}

Area of study: The study was conducted in Niger State of Nigeria. Niger State is in the North Central Zone of the country. It is situated between latitude $8^{\circ} 20^{\prime} \mathrm{N}$ and $11^{\circ} 30^{\prime} \mathrm{N}$ of the Equator and Longitudes $3^{\circ} 30^{\prime} \mathrm{E}$ and $7^{\circ} 40^{\prime} \mathrm{E}$ with a population of 3,950,249 people based on 2006 census (Niger State of Nigeria Statistical year book 2011). The state is made up of 25 local government areas (LGAs) which are divided into three senatorial districts. The major crops cultivated in the state are millet, rice, maize, 
guinea corn, beans, cassava, groundnuts, yam and sweet potatoes. Others activities engage in are animal rearing like poultry, goats and sheep and crafts works such as sculptures, weaving and blacksmith (Publication of Projects and Programmes Documentation Unit, PPDU, (2009). Shea trees are found growing abundantly in the State.

The population of the study comprised of all Shea butter processors in Niger state, Nigeria. Multi-stage sampling procedure was used to select sample for the study. The first stage was purposive selection of the Niger State Agricultural Mechanization Development Agency (NAMDA) zones A (Bida) and C (Kontagora) from the three zones in the state. The second stage involved random selection of $25 \%$ of blocks from each of the selected Zones. Three (3) blocks of Katcha, Lemu and Doko were selected from 13 blocks in zone A and four (4) blocks of Kotangora, Kaboji, Baban Rami and Borgu from 15 blocks in zone $C$. The third stage was random selection of $40 \%$ of cells from 8 cells in each of the blocks, 9 and 12 cells for $A$ and $C$, respectively. Lastly, random selection of $10 \%$ processors from the list of registered/generated Shea butter processors in each cell to give a total number of 217 processors that represents the sample size for the study. The data for the study were collected using interview schedule conducted with Shea butter processors in the study area by trained extension agents who understand the local dialect. The data were subjected to descriptive statistics such as frequencies, means and percentages and inferential statistics such as chi-square and Pearson Product Moment Correlation (PPMC).

Personal and enterprise characteristics were obtained directly from the survey. Sources of information were listed and the respondents were asked to select the ones they used to obtain information on Shea butter and ranked based on their frequency. The level of awareness was obtained by listing modern processing technologies as adapted from GIZ manual on best practices for producing quality butter and asking them to identify the ones they are aware of. Score of 1 and 0 was assign to aware and unaware, respectively. A maximum value of 29 and minimum of 6 was obtained. The mean value of 18.06 was used to categorise as high for values from 18.06 and above while low for values below 18.06 .

The level of utilisation was measured using generated modern technologies from GIZ on a three point Likert-type scale of never, sometimes and always with score of 0,1 and 2, respectively. The mean of 27.66 was used to classify level of utilisation into high for values from 27.66 and above and low for values below 27.66. Constraints was measured with 13 likely problems that can be encountered while using modern processing technologies on a three-point Likert-type scale of not a constraint $=0$, mild constraints $=1$ and severe constraints $=2$. The constraints mean weight scores was used to rank the constraints. 
Creative commons User License: CC BY-NC-ND

Abstracted by: EBSCOhost, Electronic Journals Service (EJS), Google Scholar, Journal Seek, Scientific Commons,

Food and Agricultural Organization (FAO), CABI and Scopus
Journal of Agricultural Extension

Vol. 22 (2) June, 2018

ISSN(e): 24086851; ISSN(Print); 1119944X

http://journal.aesonnigeria.org

Email: editorinchief@aesonnigeria.org

\section{Results and Discussion}

\section{Personal characteristics of respondents}

The age distribution of the respondents from table 1 shows $33.3 \%$ of the respondents were between the age ranges of $40-50$ years, $27.2 \%$ are between $31-40$ years and $25.3 \%$ are between $51-60$ years with the average age of 39.3 years. The result is in agreement with the finding of Koloche, Hamza et al. (2016) that recorded $60 \%, 36.6 \%$ and $3.33 \%$ for age ranges of $41-50$ years, $31-40$ years and $51-60$ years, respectively. The sex distribution shows $98.2 \%$ to be female while $1.8 \%$ was male. This implies that Shea butter processing is an exclusive business of the female folk.

Table 1 also shows that the majority (98.2\%) of the respondents were married, while $0.9 \%$ was single and widowed, with the respondents having a household size range of 6-10 person/household (46\%), followed by $1-5$ person/ household (25\%) and an average household size of 9.5 . This high household size can be explained according to Sanusi, Tijani and Akinsokeji (2016), that Shea butter processing is high labour intensive and the large household size of respondents ensure a constant supply of labour for processing. The respondent's education status shows that $68.2 \%$ had Quaranic education, $19.4 \%$ had no formal education while formal education accounted for $12.4 \%$. This shows high level of illiteracy in the study area. More than half $(59 \%)$ of the respondents were members of Shea butter processors association

Table 1: Personal characteristics of respondents

\begin{tabular}{lll}
\hline Variables & Percentage & Mean \\
\hline Age groups & & \\
$21-30$ & 2.3 & 39.3 \\
$31-40$ & 27.2 & \\
$41-50$ & 33.2 & \\
$51-60$ & 25.3 & \\
61 and above & 12.0 & \\
Sex & & \\
Female & 98.2 & \\
Male & 1.8 & \\
Marital status & & \\
Single & 0.9 & \\
Married & 98.2 & \\
Widow & 0.9 & \\
Household size & & \\
$1-5$ & 25.0 & 9.5 \\
$6-10$ & 46.0 & \\
$11-15$ & 23.4 & \\
$16-20$ & 5.6 & \\
Education status & & \\
No formal education & 19.4 & \\
Primary education & 7.8 & \\
Secondary education & 2.8 & \\
Tertiary education & 1.8 & \\
Quranic education & 68.2 \\
Membership of Shea butter association & & \\
Members & 59 & \\
Non-member & 41 & \\
\hline
\end{tabular}




\section{Enterprise Characteristic of Respondents}

Table 2 shows that $91.7 \%$ of the respondents used semi-mechanized method of production, while $7.4 \%$ and $0.9 \%$ of the respondents used traditional and mechanized method of production, respectively. More than half $(55.3 \%)$ of the respondents sell their Shea butter singly and the remaining ones sell both singly and collectively $(38.7 \%)$ and collectively (6\%). This can be attributed to low demand for Shea butter that makes the processors to produce the quantity which they can dispose on their own, about $52 \%$ of respondents had working experience of between 1-10 years and $24.9 \%$ had between 11-20 years working experience with an average working experience of 19.8 years. This implies that $76.5 \%$ of the processors had less than 20 years of working experience. The result is similar to that of Sanusi et al, (2016) that reported $85 \%$ of working experience of between 1-20 years in similar research in Kwara State.

The data also shows that the majority of the processors used family labour $(62.7 \%)$ while $34.1 \%$ of the processors used both family and hired labour to produced butter with $31.3 \%, 27.2 \%$ and $24.4 \%$ of them processing butter on their owed, family and community land, respectively. The Majority $(80.1 \%)$ of the processors finance their processing activities with their personal savings and $12.4 \%$ finance their processing from money gotten from relatives. This shows that the processors are not getting financial assistance from commercial banks and the processors resort to use of resources within their reach (personal and relatives). 
Creative commons User License: CC BY-NC-ND

Abstracted by: EBSCOhost, Electronic Journals Service (EJS), Google Scholar, Journal Seek, Scientific Commons,

Food and Agricultural Organization (FAO), CABI and Scopus
Journal of Agricultural Extension

Vol. 22 (2) June, 2018

ISSN(e): 24086851; ISSN(Print); 1119944X

http://journal.aesonnigeria.org

Email: editorinchief@aesonnigeria.org

\section{Table 2: Enterprise characteristics}

\begin{tabular}{|c|c|c|}
\hline \multirow{2}{*}{\multicolumn{3}{|c|}{$\begin{array}{l}\text { Variables } \\
\text { Method of production }\end{array}$}} \\
\hline & & \\
\hline Traditional & 7.4 & \\
\hline Semi- mechanized & 91.7 & \\
\hline Mechanized & 0.9 & \\
\hline Mode of sale & & \\
\hline Singly & 55.3 & \\
\hline Collectively & 6 & \\
\hline Both & 38.7 & \\
\hline Years of experience & & \\
\hline $1-10$ & 51.6 & 19.8 \\
\hline $11-20$ & 24.9 & \\
\hline $21-30$ & 10.6 & \\
\hline $31-40$ & 3.2 & \\
\hline $41-50$ & 3.2 & \\
\hline $51-60$ & 2.3 & \\
\hline 61 and above & 4.2 & \\
\hline Labour used & & \\
\hline Family & 62.7 & \\
\hline Hired & 3.2 & \\
\hline Both & 34.1 & \\
\hline Tenancy of production site & & \\
\hline Owned & 31.3 & \\
\hline rented & 1.4 & \\
\hline Family & 27.2 & \\
\hline Community & 24.4 & \\
\hline Cooperative & 9.7 & \\
\hline Both cooperative & 6 & \\
\hline owned & & \\
\hline Sources of finance & & \\
\hline Personal savings & 80.1 & \\
\hline Cooperative/association & 0.9 & \\
\hline Commercial bank & 0.9 & \\
\hline Money lenders & 5.7 & \\
\hline Relatives & 12.4 & \\
\hline
\end{tabular}

\section{Sources of Information on Shea Butter Processing Activities}

Table 3 reveals that the majority of the respondent accessed information on how to process Shea butter from family and relatives $(80.2 \%)$, followed by extension agents $(12.9 \%)$, individual $(7.4 \%)$ and radio $(2.8 \%)$ in that order. This disagrees with the result of Sanusi, et. al. (2016) that radio (96.6\%), television (92.4\%), and neighbour $(80.8 \%)$ as sources of information on Shea butter processing in Kwara State. 


\section{Table 3: Sources of information on Shea butter processing}

\begin{tabular}{lll}
\hline Sources of information & Percentage $(\%)$ & Rank \\
\hline Friends and relations & 80.2 & $1^{\text {st }}$ \\
Extension agent & 12.9 & $2^{\text {nd }}$ \\
Individual & 7.4 & $3^{\text {rd }}$ \\
Agricultural show & 4.6 & $4^{\text {th }}$ \\
Radio & 2.8 & $5^{\text {th }}$ \\
Visit to research institute & 2.3 & $6^{\text {th }}$ \\
Trade fair & 1.8 & $7^{\text {th }}$ \\
Television & 1.4 & $8^{\text {th }}$ \\
Print media & 0.9 & $9^{\text {th }}$ \\
\hline
\end{tabular}

${ }^{*}$ Multiple responses

\section{Awareness of Modern Processing Technologies}

Table 4 shows the respondents' awareness of modern processing technologies with the use of matured/clean fruits $(\mu=0.95,95.4 \%)$ as the most aware of, followed by milling machine $(\mu=0.94,94.9 \%)$, cracking of nuts gently $(\mu=0.94,94.5 \%)$, milling to fine paste $(\mu=0.93,93.5 \%)$, keep in cool and dry place $(\mu=0.93,93.5 \%)$. While the least aware modern technology was use of screw/hydraulic press $(\mu=0.02,1.8 \%)$. These technologies that the processors were aware of are the ones that ensure production of quality butter and processing activities easier.

On the overall, the level of awareness of modern processing technologies was low $(60.4 \%)$. The result contradicted the findings of Sanusi, et.al, (2016) that reported high $(55.0 \%)$ awareness level of modern processing technologies in Kwara State. This accounted for the low utilization of modern processing technology and poor quality of Shea butter produced by the processors. 
Creative commons User License: CC BY-NC-ND

Abstracted by: EBSCOhost, Electronic Journals Service (EJS), Google Scholar, Journal Seek, Scientific Commons,

Food and Agricultural Organization (FAO), CABI and Scopus
Journal of Agricultural Extension

Vol. 22 (2) June, 2018

ISSN(e): 24086851; ISSN(Print); 1119944X

http://journal.aesonnigeria.org

Email: editorinchief@aesonnigeria.org

Table 4: Awareness of modern processing technologies

Modern processing technologies Percentag Mean Rank

e

\begin{tabular}{llll}
\hline Matured/clean fruits & 95.4 & 0.95 & $1^{\text {st }}$ \\
Miller & 94.9 & 0.95 & $2^{\text {nd }}$ \\
Cracking of nuts gently & 94.5 & 0.94 & $3^{\text {nd }}$ \\
Milling to fine paste & 93.5 & 0.93 & $4^{\text {th }}$ \\
Keep in cool and dry place & 93.5 & 0.93 & $4^{\text {th }}$ \\
washing kernel/drying & 92.2 & 0.92 & $6^{\text {th }}$ \\
Scoooping of minute particles & 91.2 & 0.91 & $7^{\text {th }}$ \\
Removal of pulp immediately & 89.4 & 0.89 & $8^{\text {th }}$ \\
Use of dried/un-cracked & 88.9 & 0.89 & $9^{\text {th }}$ \\
Parboiling within 3 days & 87.1 & 0.87 & $10^{\text {th }}$ \\
Drying of parboiled nuts & 87.1 & 0.87 & $10^{\text {th }}$ \\
Air tight packaging & 82 & 0.82 & $12^{\text {th }}$ \\
Stirring with wooden ladle & 80.2 & 0.80 & $13^{\text {th }}$ \\
Boiled within 3 hours & 79.7 & 0.80 & $14^{\text {th }}$ \\
uniformly cracked kernel & 69.1 & 0.69 & $15^{\text {th }}$ \\
Knead in uniform direction & 62.7 & 0.63 & $16^{\text {th }}$ \\
All processes completed in 24 hours & 63.1 & 0.63 & $16^{\text {th }}$ \\
Roasting immediately & 54.4 & 0.54 & $18^{\text {th }}$ \\
Roaster & 51.6 & 0.52 & $19^{\text {th }}$ \\
Timing of roasting & 48.4 & 0.48 & $20^{\text {th }}$ \\
Crusher & 40.6 & 0.41 & $21^{\text {st }}$ \\
Addition of water in ratio 1:10 & 40.1 & 0.40 & $22^{\text {nd }}$ \\
Filtration through a thick cotton & 38.2 & 0.38 & $23^{\text {rd }}$ \\
Cracker & 21.2 & 0.21 & $24^{\text {th }}$ \\
Kneader & 17.5 & 0.18 & $25^{\text {th }}$ \\
Parboiling tank & 12.4 & 0,12 & $26^{\text {th }}$ \\
Heated tank/boiler & 10.1 & 0.10 & $27^{\text {th }}$ \\
Pre-cleaner & 7.8 & 0.08 & $28^{\text {th }}$ \\
Storage tank & 6.9 & 0.69 & $29^{\text {th }}$ \\
Expeller & 5.5 & 0.06 & $30^{\text {th }}$ \\
Vibrating screen & 5.1 & 0.05 & $31^{\text {st }}$ \\
Screw/hydraulic press & 1.8 & 0.02 & $32^{\text {nd }}$ \\
Overall mean 18.06 (range=29-6) SD & & & \\
4.18 & & & \\
\hline
\end{tabular}

\section{Level of Utilization of Modern Processing Technologies}

Table 5 shows the extent of use of modern processing technologies in the study area. Milling of Shea nuts into fine paste $(\mu=1.97)$ was the most utilized processing technology and ranked $1^{\text {st }}$. This is so because milling the Shea nuts into fine paste will ensure more production of butter and can be achieved regardless of method of production (traditional or mechanized). This is closely followed by use of matured, fresh and un-crack nuts $(\mu=1.91)$, keep of butter in cool and dry place $(\mu=1.90)$, scooping of minute particles on the surface of the butter $(\mu=1.87)$ and milling machine $(\mu-1.86)$ that ranked $2^{\text {nd }}, 3^{\text {rd }}, 4^{\text {th }}$ and $5^{\text {th }}$, respectively. The utilisation of these technologies can be explained from the pointed that they ensure quality and increase quantity of butter produced. The least utilised technologies are pre-cleaner, vibrating screen, screw/hydraulic press and expeller and all scoring mean value of 0.00 and 
ranking $29^{\text {th }}$. The unutilised technologies can be attributed to the fact that they do not allow the complete removal of butter from the waste, thereby reducing Shea butter production.

The level of utilization on the overall reveals low utilisation of modern technologies $(57.6 \%)$. The result agreed with the findings of Sanusi et.al. (2016) that recorded low utilisation of modern processing technology (53.8\%) in Kwara state. This can be attributed to the high cost of procuring this modern processing equipment that are aggravated by lack of credit facilities, government assistance, unavailability of modern processing technologies and poor market demand for butter.

\section{Table 5: Level of utilisation of modern processing technologies}

\begin{tabular}{|c|c|c|}
\hline Modern technology & Mean & Rank \\
\hline Milling to fine paste & 1.97 & $1^{\text {st }}$ \\
\hline Matured/clean fruits & 1.91 & $2^{\text {nd }}$ \\
\hline Keep in cool and dry place & 1.90 & $3^{\text {rd }}$ \\
\hline Scooping of minute particles & 1.87 & $4^{\text {th }}$ \\
\hline Miller & 1.86 & $5^{\text {th }}$ \\
\hline Cracking of nuts gently & 1.78 & $6^{\text {th }}$ \\
\hline Use of dried/un-cracked & 1.75 & $7^{\text {th }}$ \\
\hline Removal of pulp immediately & 1.67 & $8^{\text {th }}$ \\
\hline Stirring with wooden ladle & 1.48 & $9^{\text {th }}$ \\
\hline Parboiling within 3 days & 1.42 & $10^{\text {th }}$ \\
\hline Air tight packaging & 1.36 & $11^{\text {th }}$ \\
\hline Drying of parboiled nuts & 1.19 & $12^{\text {th }}$ \\
\hline Boiled within 3 hours & 1.16 & $13^{\text {th }}$ \\
\hline washing kernel/drying & 1.15 & $14^{\text {th }}$ \\
\hline uniformly cracked kernel & 0.97 & $15^{\text {th }}$ \\
\hline Knead in uniform direction & 0.89 & $16^{\text {th }}$ \\
\hline All processes completed in $24 \mathrm{hrs}$ & 0.72 & $17^{\text {th }}$ \\
\hline Filtration through a thick cotton & 0.61 & $18^{\text {th }}$ \\
\hline Addition of water in ratio $1: 10$ & 0.39 & $19^{\text {th }}$ \\
\hline Crusher & 0.38 & $20^{\text {th }}$ \\
\hline Roasting immediately & 0.36 & $21^{\text {st }}$ \\
\hline Timing of roasting & 0.33 & $22^{\text {nd }}$ \\
\hline Roaster & 0.25 & $23^{\text {rd }}$ \\
\hline Kneader & 0.12 & $24^{\text {th }}$ \\
\hline Cracker & 0.07 & $25^{\text {th }}$ \\
\hline Storage tank & 0.06 & $26^{\text {th }}$ \\
\hline Parboiling tank & 0.04 & $27^{\text {th }}$ \\
\hline Heated tank/boiler & 0.03 & $28^{\text {th }}$ \\
\hline Vibrating screen & 0.00 & $29^{\text {th }}$ \\
\hline Pre-cleaner & 0.00 & $29^{\text {th }}$ \\
\hline Expeller & 0.00 & $29^{\text {th }}$ \\
\hline Screw/hydraulic press & 0.00 & $29^{\text {th }}$ \\
\hline $\begin{array}{l}\text { Overall mean } 27.66 \text { (range }=45-5 \text { ) SD } \\
5.55\end{array}$ & & \\
\hline
\end{tabular}

\section{Constraints to Use of Modern Processing Technologies}

Table 6 shows the constraints to use of modern processing technologies. Lack of credit facility $(\mu=1.72)$ ranked highest as most severe constraint to use modern processing technologies. Closely followed to this are lack of government assistance $(\mu=1.68)$, high cost of processing equipment $(\mu=1.67)$, lack of working materials $(\mu=1.60)$ and lack of modern processing technologies $(\mu=1.55)$. Lack of credit and government assistance are the root causes of the other problems of high cost of 
processing equipment, lack of working and processing technologies that eventually affect the level of utilization of modern processing technologies. This is so because the modern processing equipment are very expensive and the processors are at the mercy of Non-governmental and governmental agencies to assist them in procuring the equipment. Others are felling of trees $(\mu=1.48)$, scarcity of Shea nuts $(\mu=1.48)$, lack of electricity $(\mu=1.38)$, poor income accruing to processor $(\mu=1.38)$, low demand of Shea butter $(\mu=1.31)$. Felling of Shea trees leads to scarcity of the Shea nuts that affect the psychology of the processors to see reason why they should use modern technology since the nuts may not be available sometimes. Electricity is very essential to run the machine but is usually not available in the rural areas. This could also affect the utilisation of modern processing technology. Poor income accruing to processors from the sale and low demand for Shea butter are other constraints that can affect utilisation of modern processing technologies because there may not much economic gain that would have motivated them to acquire the equipment.

Table 6: Constraint to use the modern processing technologies

\begin{tabular}{lll}
\hline Constraints & Mean & Rank \\
\hline Lack of credit facility & 1.72 & $1^{\text {st }}$ \\
Lack of government assistance & 1.68 & $2^{\text {nd }}$ \\
High cost of processing equipment & 1.67 & $3^{\text {rd }}$ \\
Lack of working materials & 1.60 & $4^{\text {th }}$ \\
Lack of modern processing & 1.55 & $5^{\text {th }}$ \\
technologies & & \\
Felling of trees & 1.48 & $6^{\text {th }}$ \\
Scarcity of Shea nuts & 1.45 & $7^{\text {th }}$ \\
Lack of electricity & 1.38 & $8^{\text {th }}$ \\
Poor income accruing to processor & 1.37 & $9^{\text {th }}$ \\
Low demand of Shea butter & 1.31 & $10^{\text {th }}$ \\
Lack of water & 1.26 & $11^{\text {th }}$ \\
High cost of maintenance & 1.16 & $12^{\text {th }}$ \\
Lack of storage facility & 1.14 & $13^{\text {th }}$ \\
Inadequate machine to go round & 1.06 & $14^{\text {th }}$ \\
Lack of technical knowledge & 1.00 & $15^{\text {th }}$ \\
\hline
\end{tabular}

\section{Relationship between Age, Years of Experience, Constraints and Awareness and Level of Utilization of Modern Processing Technologies}

Table 7 shows the relationship of age, years of experience, constraints and awareness of the respondents with the level of utilization of modern processing technologies to be positive. That is the higher the respondents' age, year of experience, constraints and level of awareness, the higher the level of utilisation of modern processing technology. Age and years of experience can be explained together from the fact that as the age and years of experience of the respondents' increases, they tend to constantly searching for better ways to make their work easier and to produce more Shea butter, which increases their aware on modern processing technologies, hence influence the level of utilization of modern processing technologies.

Increase in level of awareness of modern processing technologies by the respondents is expected to lead to increase in the level of utilisation because they will likely experiment with them and those that give good results will be adopted and 
utilized. Sanusi et al. (2016) also recorded a positive relationship between years of experience and awareness with level of utilisation of modern processing technologies in Kwara state. Constraints show a positive correlation with the level of utilization. This finding disagrees with Sanusi et al. (2016) that reported a reverse relationship between constraints and level of utilisation. This is an unexpected result, since we expected the constraints to negatively correlate with level of utilization. This can be explained from the fact that as the respondent age and years of experience increases, they are better aware of the prospects and constraints to use modern processing technologies and they are devising means to remove the obstacles to enhance the utilisation of modern processing technologies. Similar in the study area, there are lots of interventions from government agencies and Non-governmental agencies which help to remove the problems associated with the use of the technologies by providing modern processing technologies in some locations in the state, which could influence their utilisation.

Table 7: Relationship between age, years of experience, constraints and awareness and level of utilization of modern processing technologies

\begin{tabular}{ll}
\hline Variable & r-value \\
\hline Age & $0.245^{*}$ \\
Years of experience & $0.198^{*}$ \\
Awareness & $0.792^{*}$ \\
Constraints & $0.152^{*}$ \\
\hline
\end{tabular}

${ }^{*} \mathrm{P} \leq 0.05$

\section{Conclusion and Recommendations.}

The level of utilisation and awareness of modern processing technologies were low, despite the intervention by the state government and GIZ in the state. Specifically, the interventions were located in each of the senatorial district of the state where one processing centre was cited in Farin Shinge in Kotangora LGA, Asanyin in Katcha LGA and Kodo in Chanchaga LGA. Niger State Commodity Export Promotion Council (NSCEPC) should make effort to increase the number of Shea butter processing villages in each senatorial districts to bring the technologies closer to the processors, thereby improve the level of awareness and utilization of modern processing technologies as well as improve the capacity of the Shea butter processors.

The level of literacy of the processors was low which may affect their utilization level. Though GIZ translated their processing manual package into the major languages of Hausa and Nupe to address the problem but the distribution coverage of the manuals may not be adequate and the inability of the processors to read the manual may affect the adoption and utilisation of the technologies. Niger State Commodity Export Promotion Council and other development partners should make effort to translate the GIZ package manual on Shea butter best practices that contain simple guide to following in order to produce quality butter to other dialects in the state because of high level of illiteracy among the processors. This could improve their level of awareness and level of utilization. Extension agency in the state should invigorate 
their programme to include Shea component through which training will be given to the processors to enhance their production capacity in terms of quantity and quality.

\section{References}

Addaquay, J. (2004). The Shea butter value chain: refining in West Africa. West Africa Trade Hub(WATH). Technical Report No. 3. Washington, DC: USAID.

Ademola, A.O., Oyesola, O.B. and Osewa, S.O., 2012. Assessment of Shea butter processing among rural dwellers in Atisbo Local Government Area of Oyo state, Nigeria. European Journal of Business and Social Sciences Vol. 1. No. 6: Pp. 1-8.

Akinsokeji, O.A., S.A. Tijani, M.K. Sanusi, L. Igene and M.O. Orifah, (2017) Perception of modern processing technology by Shea butter processors in Kwara State, Nigeria. Journal of Agricultural Extension, 21(1): 1-14.

Daniel, A. O., Olafimihan, E. Kwaya and O. Odejide.2005.Shea nut processing: Raw Material update. A Bi-annual publication of Raw Materials Research and Development Council Vol. 5. No.2

Ebayahaya M. (2014) GIZ-SEDIN Shea exit strategy: Pro-Poor Growth and Empowerment Promotion (SEDIN) Programme, Niger State, Nigeria. Deutshe Gesellschaft Fūr internationale Zusammenarrbeit (GIZ)/National Planning Commission, Nigeria. Pp.:1-16.

Igene L, Sedibe M. M, Solomon O, Van der Westhuizen C and Fadeyi O. A (2017)Processors' training needs on modern Shea butter processing technologies in North Central Agro-ecological zone of Nigeria. South African Journal of Agricultural Extension. Vol.45 (1) Pp.: 41-48

Koloche I. M, Hamza A. M, Mohammed A, Yahaya S. A, Garba H. M and Oladipo O. F (2016) The quantity of Shea nuts assessed collected and process using improved Shea nut processing technologies in Niger State. American Journal of Experimental Agriculture.Vol.12 (2) pp.: 1-10

Koloche I.M, Olaleye R.S, Adeniji O.B, Yahaya S.A, Umar S.I.M, Tsado J.H. (2016). Socio-Economic characteristics and constraints associated with the adoption of the improved Shea nut processing technologies in Niger State, Nigeria. Greener Journal of Agricultural Sciences. Vol. 6 (1), pp. 001-009.

Niger State of Nigeria. Statistical year book (2011) edition. Bureau of statistics, Niger State Planning Commission, Niger State. Facts and figures on Niger state. Pp. iv-vi. Accessed online from http://rvision.org/epubl/facts\%2520and\%2520figures\%2520about\%2520Ni... on $17^{\text {th }}$ May 2015.

Publication of Projects and Programmes Documentation Unit (PPDU) (2009) Office of the Governor, Niger State Government. Pp.: 2-17.

Sanusi, M. K, Tijani, S.A and Akinsokeji, O.A. (2016) Level of utilisation of modern processing technologies among Shea butter processors in Kwara State, Nigeria. Nigerian Journal of Rural Sociology. Vol. 16 (4) Pp.: 39-45. 